\title{
pro.posições
}

$e$-ISSN 1980-6248

http://dx.doi.org/10.1590/1980-6248-2016-0096

ARTIGOS

\section{Jovens sem miséria: estéticas de uma economia do dispêndio ${ }^{1}$}

\section{Youth without misery: aesthetics of an economy of expenditure}

(i) Professor Adjunto da Faculdade de Educação da UERJ, Docente do Programa de Pós-Graduação em Educação - ProPEd - UERJ e Docente do Programa de Pós-Graduação em Educação, Cultura e Comunicação em Periferias Urbanas - PPGECC Universidade do Estado do Rio de Janeiro - UERJ, Rio de Janeiro, RJ, Brasil, http://orcid.org/0000-0001-7682-4717, coelhoguga@gmail.com.

Resumo: Este artigo se dedica a abordar alguns trechos de relato etnográfico, entrevistas e imagens, gerados em um universo de práticas culturais jovens marginalizadas, especialmente a piXação e as turmas de Bate-Bola, ambas muito populares nos subúrbios e nas favelas cariocas, cruzando-os com os conceitos de communitas/liminaridade em Turner e de dispêndio em Bataille. Desse cruzo empírico-teórico, sugere-se que tais maneiras de viver, justamente subjetividades das mais negligenciadas nas escolas e nas cidades, oferecem em suas performances, em seus acabamentos éticos e estéticos, bons indicativos para entender as razões epistemológicas de suas incompatibilidades ao receituário normativo, ou seja, escancaram os limites economica e libidinalmente miseráveis das máquinas de subjetivação que fomentam suas exclusões; justamente porque não cabem, transbordam. Nietzsche, Castoriadis e Maffesoli reforçam o aparato teórico neste trabalho.

Palavras-chave: juventude, epistemologia, estética, subjetividade

\footnotetext{
1 Apoio: Fundação Carlos Chagas Filho de Amparo à Pesquisa do Estado do Rio de Janeiro - FAPERJ
} 


\section{pro.posıções}

$e$-ISSN 1980-6248

http://dx.doi.org/10.1590/1980-6248-2016-0096

Abstract: This paper dedicates itself to approaching some ethnographic report excerpts, interviews and images, generated in a universe of marginalized youth cultural practices - especially the piXação and Bate-Bola groups, both very popular in the suburbs and slums of Rio de Janeiro - comparing them with the Turner's concepts of communitas/liminality and with Bataille's expenditure. From this empirical and theoretical junction, the paper suggests that such ways of living, indeed some of the most neglected subjectivities of our schools and cities, offer in their performances, in their ethical and aesthetical qualities, good indicators to understanding the epistemological grounds of their incompatibility to the normative prescriptions, i.e., they evidence the economically and libidinally miserable limits of the subjectivity machines that foment their exclusion; precisely because they do not fit in, they overflow. Nietzsche, Castoriadis and Maffesoli, reinforce this work's theoretical apparatus.

Keywords: youth; epistemology; aesthetics; subjectivity

Iniciemos com um trecho de uma conversa com um rapaz piXador ${ }^{2}$, chamado Nuno. Ao ser convidado a pensar sobre a dimensão piXadora de sua vida em comparação às demais instâncias de seu cotidiano, ele empreende uma espécie de relaxamento à dimensão "dirigida" de si, suspendendo, então, temporariamente, suas propriedades, aquelas que lhe conferem posição social e que compõem, digamos, sua "biografia oficial", substituindo, inclusive, seu nome oficial por um nome fantasia:

O que paga a minha conta, o que alimenta a minha filha é o Leandro. O Nuno é um personagem que está ai, é uma coisa que en faço. São duas vidas, a noturna e a diurna. Quem está aqui é o Leandro falando sobre o Nuno. O Nuno é maluco, não quer porra nenhuma. Nuno não trabalha, não estuda, não tem filha. O Nuno é maluco, sobe em cabo de aço de prédio de 10 andares. Passa pendurado em viadutos. Não trabalha, fica arriscando a vida por aí. O Nuno é louco, nem chama que ele vai fazer merda aqui. Ele vai roubar tua câmera. (Nuno, piXador e ex-torcedor organizado, em entrevista realizada em abril de 2010)

Aqui, esse roubo possível da câmera é uma alegoria disfarçada de "apenas" piada, mas que carrega uma sabedoria milenar recorrente em diversos ritos de passagem, onde, para lambuzar a sociedade com o que ela tem de comum e reatar os laços que a hipertrofia da estrutura social possa ter ameaçado, é preciso, mesmo que temporariamente, de forma geralmente sazonal, suspender as propriedades, interditar os prestígios sociais, balançar as hierarquias, bagunçar os códigos. No caso, então, é significativo perceber que entre as duas

\footnotetext{
2 Sempre, no percurso textual, a palavra piXação e suas derivadas virão com "X" maiúsculo em simpatia à mesma utilização de Canevacci em Culturas eXtremas (2005). Fazendo também uma analogia entre o enigma como conceito importante neste trabalho e a letra-símbolo "X" que, em diversos contextos, representa a presença da incógnita.
} 


\section{pro.posıções}

$e$-ISSN 1980-6248

http://dx.doi.org/10.1590/1980-6248-2016-0096

personalidades em questão, o Leandro e o Nuno, aquele que dá entrevista, que, portanto, investe em um pensamento dirigido na tentativa de falar de si, é o Leandro, o mesmo que possui um emprego, que tem família, que provê alimento às filhas, enquanto o Nuno, este que ali nem "está", se estivesse, "despossuído" que é, sem família, trabalho ou filhas, supostamente nos desapossaria do instrumento que na ocasião nos distinguia - a câmera de vídeo. Muito embora tenhamos filmado por diversas vezes o Nuno em ação como piXador, correndo riscos, escalando pontes e prédios enormes, e em nenhum desses momentos ele tenha efetivamente tentado roubar a câmera, o que mais importa aqui é que, no momento em que o Leandro resolveu falar sobre esse seu "duplo outro", do qual fez questão de manter discursivamente distância e claro antagonismo, ele usou as características vinculadas à loucura, a "fazer merda", a não trabalhar nem estudar, e ao roubo - justamente aquelas que excedem as distinções corriqueiras da estrutura social e que figuram como atividades irresponsáveis quanto a uma agenda de futuro. Assim, entre Leandro e Nuno, numa dimensão individual, portanto, parece que podemos sentir bem o jogo contínuo entre o "eu" trabalhador diurno, acumulador de emblemas distintivos, ou seja, de propriedades e que, por meio delas, se estabelece socialmente; e o outro, Nuno, uma espécie de "alterego", um negativo que, pela dissolução das posses e pela desobediência aos padrões de comportamento previstos à posição social do seu "duplo", permite a esse mesmo corpo eventuais doses, intensas nesse caso, de reintegração a um dinamismo que precede as estruturas, deixando passar à aparência essa imanência do agitado múltiplo interno, inapreensível, que trabalha noturnamente, impedindo que o papel social esgote a potência plural do sujeito. Nesse ponto, então, encontramos um "nó" primordial: se é a integração e a adaptação completa à estrutura social que o monopoliza, e suas propriedades materiais e imateriais, suas distinções, que assumem o comando absoluto de sua "crença" em si; se, então, só houver "Leandro", você estará sob sério risco de desintegração por assepsia cadavérica. Em todo caso, se, por outro lado, o entorpecimento da obscuridade viscosa sem nome, sem distinção, sem propriedades, e se, então, o "Nuno" o sequestra por completo, o seu risco é o mesmo, de desintegrar-se, porém, pela via da implosão centrífuga de si. Em ambos os casos, portanto, estamos diante da ameaça da morte sem renascimento, fantasma primordial, cuja ameaça a humanidade sempre, de uma forma ou de outra, sentiu e dedicou-se com afinco na sua terapêutica remediação, nos oferecendo assim um repertório infindável de rituais que periodicamente precisavam ser postos em ato para que a saúde do grupo fosse garantida. Uma preocupação que, mesmo em nossa sociedade moderna civilizada ocidental, crente na libertação 


\section{pro.posıções}

$e$-ISSN 1980-6248

http://dx.doi.org/10.1590/1980-6248-2016-0096

dos rituais que supostamente a conquista da razão dirigida teria lhe concedido, segue presente, haja vista a proliferação das terapias orientais nos grandes centros urbanos, o retorno de religiosidades alternativas, a moda das terapias místicas entre artistas famosos, os "espaços zen" dentro de aeroportos e até em grandes empresas, ou, sendo mais popular e brasileiro, as atuais enormes filas nos dias de consultas abertas nos terreiros de umbanda e igrejas evangélicas, "a cervejinha sagrada" das sextas-feiras, assim como todos os excessos juvenis que aqui me interessam mais propriamente. Em discurso muito parecido com o do Nuno, Tatá, também piXador, chega a apontar exatamente essa preocupação:

Eu son o Tatá, mas na verdade eu son o João. O Tatá é um modo do João talvez. se divertir, talvez viver algumas aventuras diferentes do cotidiano do João. Eu, como Tatá, desafio qualquer parada, como João eu não desafio ninguém, compadre. Então é isso, mas nunca deixar o Tatá se tornar o João. Porque se depender do Tatá, o Tatá não vai querer trabalhar, Tatá só vai querer piXar, compadre. (Tatá, em entrevista realizada em abril de 2010)

Preocupação evidente na atenção que ele julga ser necessária ter para não deixar o "Tatá" arrastar o João e apoderar-se por completo do ser. Nessa dinâmica, então, que é preciso balancear entre a perda das propriedades estruturais e a sua reintegração de posse entre, então, uma comunhão com o comum possibilitada pela morte temporária de "si" e a retomada do curso pelo renascimento, a modernidade ocidental se deteve no estágio de "curso", de "progresso" que agora não precisaria mais ser interrompido por nada, não oferecendo lugar nessa lógica linear, nem para a morte nem para o renascimento, optando consequentemente em ver o fantasma da morte por assepsia cadavérica tornar-se não mais apenas uma ameaça dinamizadora, ou seja, positiva, mas paralisante desse movimento perpétuo, mortal por anestesia no sentido etimológico mesmo, interrompendo a "estética", o vitalismo da vida em sua exuberância. Pensando assim, portanto, é possível imaginar que uma sociedade que alcançou tal nível de predominância do progresso, na mesma medida tenha também sacralizado o que é “intocável”, a propriedade, e que consequentemente, se esse é o último estágio de fragmentação possível, podemos pensar de forma pessimista como Freud, no extermínio do último homem pela impossibilidade de contenção de tanto acúmulo de energia sem dispêndio, para a qual a bomba atômica é o aparato por excelência, ou otimista como Maffesoli que sente nas tendências de nossa época, justamente pela simpatia que há pelo dispêndio de energia, em especial entre as culturas jovens, o anúncio de uma nova rearmonização do mundo, o que naturalmente não significa o anúncio de um futuro equilibrado ideal. 


\section{pro.posições}

$e$-ISSN 1980-6248

http://dx.doi.org/10.1590/1980-6248-2016-0096

Pois bem, um antropólogo que tratou desse balanceamento mais ou menos geral na humanidade foi Victor Turner (1974), estudando o papel desse manejo das "propriedades do si”, suas perdas sazonais propositais, na manutenção dos laços societais em diversos cenários culturais, dos hippies aos ndembo, passando pela ordem de São Francisco.

Nestas fontes, tanto religiosas quanto seculares, mantém-se uma conexão bastante regular entre liminaridade, inferioridade estrutural, a mais baixa posição social e estrangeirice estrutural, de um lado e de outro, valores humanos como paz, harmonia entre todos os homens, fecundidade, saúde do espírito e do corpo, justiça universal, camaradagem e fraternidade entre todos os homens, igualdade diante de Deus, da lei, ou a força da vida de homens e mulheres, jovens e velhos, e de pessoas de todas as raças e grupos étnicos. Em todas essas formulações utópicas tem especial importância a permanente conexão entre igualdade e ausência de propriedade. ( pp. 163-164)

Trata-se de uma sabedoria arcaica milenar largamente sedimentada, sempre muito presente nesses saberes populares, de que a própria manutenção da estrutura social depende de periódicos empenhos na sua dissolução temporária, o que põe seus membros numa espécie de zona de "liminaridade", na qual, "desprotegidos" de seus emblemas, possam embeber o grupo da substância que os mantém agregados, a "communitas", sendo esses dois conceitos o cerne dessa obra de Turner. Por liminaridade, então, Turner entende uma zona social, imaginária e psíquica para onde são conduzidos, via ritos preparatórios específicos, membros de determinado grupo que, seja para passarem na sequência por rituais de iniciação, de passagem ou por eventos sazonais coletivos de inversão de hierarquia, necessitam para isso submeter-se a um processo de desapropriação de tudo aquilo que o estabiliza na estrutura social. Assim, é como se morressem um pouco, portanto, igualando-se, ou ao menos aproximando-se dessa forma, a esse estado de vínculo comunal indistinto que ele chamou de communitas, um "laço humano essencial e genérico, sem o qual não poderia haver sociedade" (p.119) e que percebeu como motivação predominante em rituais e festividades nas mais diversas realidades sociais. Em suas palavras:

Os atributos da liminaridade ... são necessariamente ambíguos, uma vez que esta condição e estas pessoas furtam-se ou escapam à rede de classificações que normalmente determinam a localização de estados e posições num espaço cultural.... Assim, a liminaridade frequentemente é comparada à morte, ao estar no útero, à invisibilidade, à escuridão, à bissexualidade, às regiões selvagens e a um eclipse do sol ou da lua. (p. 117)

Cabe destacar, o que se torna bastante proveitoso ao nosso caso em particular, o papel paradoxalmente importante que Turner percebe ser assumido nos mais diversos rituais, 


\section{pro.posições}

$e$-ISSN 1980-6248

justamente por aqueles que, na estrutura social, ocupam posição hierárquica mais baixa, inferior, assumindo assim um tipo de "força do mais fraco", ou aqueles que dessa inferioridade tramam "escapadas" às legislações, a "força do marginal", ambas costumeiramente associadas no fortalecimento dos laços comunais.

Resumindo, os superiores estruturais, por suas dissenções sobre interesses particulares ou setoriais, trouxeram a desgraça para a comunidade local. Compete então aos indivíduos estruturalmente inferiores, representando a "communitas" ou a comunidade global que transcende todas as divisões internas, restabelecer as coisas em seu devido lugar. ... A forma estrutural despoja-se dos atributos egoístas e se purifica pela associação com os valores da "communitas". A unidade que fora quebrada pela discórdia egoísta e por ocultos maus sentimentos é restaurada por aqueles que são normalmente considerados estarem situados abaixo da batalha pelas posições jurídicas e políticas. Mas a palavra "abaixo" tem dois sentidos: não significa somente o que é estruturalmente inferior; significa também a base comum de toda vida social, a terra e seus frutos. (Turner, 1974, pp. 222-223)

A "communitas" irrompe nos interstícios da estrutura, na liminaridade; nas bordas da estrutura, na marginalidade; e por baixo da estrutura, na inferioridade. Em quase toda parte a "communitas" é considerada sagrada ou "santificada", possivelmente porque transgride ou anula as normas que governam as relações estruturadas e institucionalizadas, sendo acompanhada por experiência de um poderio sem precedentes. (Turner, 1974, p. 156)

Percepção muito próxima daquela de Bakhtin (2013), quando estudou as manifestações populares carnavalescas na Idade Média e reconheceu em todas as imagens do "baixo", especialmente do baixo corporal, dos excrementos, a ambivalência da morte e do renascimento revigorante: "As imagens dos excrementos e da urina são ambivalentes como todas as imagens do 'baixo' material e corporal: elas simultaneamente rebaixam e dão a morte por um lado, e por outro dão à luz e renovam” [ênfase no original] (p. 130).

Por outro lado, no entanto, esse espaço de ambivalências é liminar justamente por nem estar dentro da estrutura e nem absolutamente fora dela, uma vez que, paradoxalmente, a continuidade do funcionamento dessa estrutura é intimamente dependente da força que é convocada para fissurá-la durante um tempo - a "communitas". Resumidamente, esse sistema opera no reconhecimento da capacidade criadora e dinamizadora da desconstrução. Retomamos aqui, rigorosamente, o mesmo "nó" que anteriormente apontamos entre o "Leandro" e o "Nuno", e entre o "João" e o "Tatá", quando tanto a ditadura de um quanto a de outro representam o mesmo risco de morte sem renascimento. Digamos, com isso, que a estrutura opera pela divisão, pela distribuição de papéis, pela gestão dos prestígios, enquanto a 


\section{pro.posições}

http://dx.doi.org/10.1590/1980-6248-2016-0096

\section{$e$-ISSN 1980-6248}

"communitas" regruda jubilosamente os separados ao todo comum, numa "correta relação mútua" (Turner, 1974, p. 215). De tal maneira, impede que a estrutura se hiperestruture, desenhando, assim, uma espécie de autodefesa diante da tendência, própria de tal processo estruturante, que, como vimos, ameaça jogar a comunidade numa patológica assepsia cadavérica, o que tornaria essa necessária suspensão eventual das propriedades para se "sentir a comunidade", uma impossibilidade epistêmica. É nisso, a meu ver, que se cava boa parte das crises emergentes na pós-modernidade, uma vez que a modernidade teria reagido a essa potência da "communitas" e lutado, com tanto entusiasmo, pela manutenção de suas "propriedades", que acabou fazendo da "communitas" não mais uma ambivalente ameaça salutar a ser vivida e gestada ritualmente, como faziam esses que Turner estudou, mas um perigo que precisa, a todo custo, ser de uma vez por todas superado, ou seja, fazer do enigma da vida um segredo passível de desvelamento pleno. Daí que somos resultantes de uma carência de ritos de passagem, cujos efeitos danosos em nossa psiquê não podem ser muito bem medidos. A pós-modernidade seria, então, nesse caso, a reencenação obscena do alto custo inescapável à tão vigorosa negação do “devir comunidade", ou seja, da importância mágica da experiência de, desarmadurados, sermos atravessados radicalmente pela coletividade. Como bem indicou também Turner (1974): "Certo é que nenhuma sociedade pode funcionar adequadamente sem esta dialética. O exagero da estrutura pode levar a manifestações patológicas da communitas, fora da lei ou contra ela "[ênfase no original] (p. 157).

A hipótese que ora defendo, portanto, é a de que determinadas eticasestéticas jovens marginalizadas, são, em boa medida, movidas de maneira paroxística por essa vontade de “communitas". Jovens, então, que compõem com vasto repertório de visualidades, de poéticas, de gestos, de humores, de experiências estéticas intensas, uma espécie de zona de resistência político-subjetiva à operação colonizatória moderna que, agindo na subjetividade, produziu impedimentos epistêmicos à aceitação de que há sentido no não sentido (Castoriadis, 2009) dessas exuberâncias "inconsequentes” e há importância inescapável do enigmático, dessa liminaridade sem razãa no adubo do que é comum. Impõem dessa forma, portanto, aquele que é, a meu ver, o maior desafio a nós, tributários da subjetividade moderna, do cogito cartesiano - a perda da propriedade erguida com maior preciosismo pela modernidade, mais endurecida que qualquer muralha - a propriedade do sentido. 


\section{pro.posıções}

$e$-ISSN 1980-6248

http://dx.doi.org/10.1590/1980-6248-2016-0096

Em um mundo que nos últimos séculos fez campanha pela aquisição, desapropriando o sentido da função que a dimensão da perda assume em todas as sociedades, esses empreendimentos, feitos de maneira espontânea por esses jovens que pesquiso, reconhecem a melhor acepção de "luxo" e de "dispêndio" desinteressado. Gastar energia, esculpindo formas do impensado, sem solicitar o lucro da posse do sentido, assim, essas estéticas parecem dar esperanças a Bataille que, em 1933, já denunciou a falta de capacidade da "humanidade consciente" em reconhecer a importância do dispêndio improdutivo. "É triste dizer que a humanidade consciente permaneceu menor: ela se reconhece o direito de adquirir, de conservar, ou de consumir racionalmente, mas exclui, em princípio, o dispêndio improdutivo" (Bataille, 2013, p. 20).

Vamos, então, a um conjunto de relato etnográfico e imagens, acompanhando uma turma de Bate-Bolas ${ }^{3}$ chamada "Legalize", que se concentra numa garagem entre os bairros de Colégio e Rocha Miranda, no subúrbio do Rio de Janeiro. Vale destacar que a cultura dos BateBolas não é compreendida aqui como "separada" da piXação. Em meu trabalho, devido ao vasto fluxo de piXadores nas turmas de Bate-Bola e de Bate-Bolas piXadores, como poderemos perceber em algumas pistas do relato etnográfico subsequente, prefiro tratá-las como parte de uma espécie de cosmologia rueira do Rio de Janeiro, compartilhando sujeitos, valores, éticas, estéticas, rivalidades, e que ainda inclui as Torcidas Organizadas de Futebol e as Galeras Funk, amplitude de que, dada a evidente vastidão, não objetivamos dar conta neste artigo.

Pois bem, a chegada a esse grupo específico se deu por uma via um tanto aleatória à pesquisa, mas que me parece rico narrar. Minha esposa é estilista de moda e, vez ou outra, eu a acompanho até as imediações da Pavuna, próximo a Costa Barros, onde fica a casa de uma das costureiras com quem ela trabalha, a dona Beth. Sempre gostei de ir junto com ela, pois, a despeito da relação de trabalho que elas têm, dona Beth, além de ser boa de papo, acolhedora, tinha um sobrinho da Torcida Organizada Fúria Jovem do Botafogo, o qual segundo ela, sempre arrumava encrencas. Então, quando os assuntos atravessavam esse campo de uma juventude que me interessa, ela parecia lidar com isso, não como sendo algo extraordinário, repugnante, mas mantinha certa serenidade como quem, mesmo reprovando as "encrencas", tinha essas práticas jovens em seu repertório. Foi lá, então, em sua sala que soube que ela estava costurando

\footnotetext{
${ }^{3}$ Turmas que desenvolvem autonomamente fantasias com temáticas ao mesmo terrificantes e infantis, e que saem em bando durante o carnaval, provocando algazarras e estabelecendo rivalidades entre elas.
} 


\section{pro.posıções}

http://dx.doi.org/10.1590/1980-6248-2016-0096

$e$-ISSN 1980-6248

as fantasias de uma turma de Bate-Bolas, prática que, como eu já sabia e já apontei aqui, integra essa rede toda entre torcidas, piXação e baile funk, de onde vem meu material etnográfico.

- Então, eu só faço as dessa turma porque eu conbeço o líder deles e ele sempre me paga certinho, ele é bombeiro. Tem muitas ai que ficam te enrolando, que tem gente ruim metida no meio, ai eu nem pego, nem aceito - me disse dona Beth.

- Passa o contato dele então, você acha tranquilo de eu ir lá acompanhar a saída deles?

- É sim, acho que salta na estação de Colégio e dá pra ir, tem que andar um pouquinho. Mas eu só indico porque eles são tranquilos. Lá em Marechal Hermes sempre me chamam pra ir, mas eu nunca vou, todo ano tem confusão, briga, tiro, ano passado mesmo morreu gente. Eu vou fazer o que lá? Vou nada. Lá tem muita turma que mistura tudo, na mesma turma tem bandido, tem polícia, aí se der algum problema, já viu. Então, nem me chama que eu não vou e nem faço fantasia pra não ter que receber gente aqui que eu não sei qual $e ́$ - alertou Beth, já indicando essa qualidade de impureza que atravessa toda nossa cultura popular, essa de colocar juntos, associados, tanto agentes institucionais de controle, quanto camadas marginais da cidade.

- Então, fala com ele, sim, passa o telefone que eu vou, sim.

- Tudo bem, eu acho que fica lindo, quando eles saem, os fogos, tudo é muito bonito de se ver, mas eu já estou velha, não vou pra não me meter em confusão à toa. É bonito também na terça de carnaval, quando vão praticamente todas as turmas do Rio ao centro da cidade, desfilar pela Av. Rio Branco, mas também acaba tendo muita briga. Imagina todas as turmas no mesmo lugar, mas se você quer, é bom ir. E tem muitas que na quarta-feira de cinzas tacam fogo nas próprias fantasias, e olha que custam caro, vin? Fazem logo uma fogueira na praça.

- É? Mas por quê?

- Diz que é pra não ter jeito de nenhuma outra turma pegar o teu bate-bola ${ }^{4}$, então você mesmo queima. Nem todas fazem, mas algumas faz̧em isso, porque se o outro pegar teu bate-bola é uma bumilhação pra você.

Então, semanas depois, quando já se aproximava o carnaval de 2014, entrei em contato com o chefe da turma, o Robinho. A Beth já havia falado de mim para ele. Combinamos, então,

\footnotetext{
4 “O bate-bola" aqui, segundo o sentido dado por eles, significa a fantasia e as alegorias.
} 


\section{pro.posições}

$e$-ISSN 1980-6248

http://dx.doi.org/10.1590/1980-6248-2016-0096

de eu chegar lá no sábado por volta do meio-dia, quando começariam os preparativos para a saída da turma, que aconteceria, segundo planejamento, somente em torno das $21 \mathrm{~h}$.

Chegado o dia, desembarquei na estação de Colégio do metrô e fui andando por uma rua principal que, segundo tinha visto, após cerca de 15 minutos de caminhada me faria chegar lá. Durante a caminhada, ouvi ao longe um som bem potente tocando funk. Passo a passo, o som ia aumentando de volume, até que avistei uma garagem aberta onde um carro, na calçada, com porta-malas aberto e potentes caixas de som disparava por todo redor seus decibéis funkeiros. Assim que me aproximei, vi alguns meninos com meias-calças e luvas coloridas em cores neon. Imediatamente, conhecendo essa comum vestimenta entre os bate-bolas, percebi logo que se tratava da garagem de uma turma. Cheguei a pensar que poderia ser a Legalize, mas não se encaixava com o endereço que me fora dado. Era então alguma outra. Caminhei um pouco mais, e o som do funk começou a se embolar, era um outro carro, cujo som de alta potência já alcançava meus ouvidos. Havia de ser outra turma. De fato era. Novamente, uma garagem, um carro funkeirizado, meninos com meias-calças coloridas tomando suas cervejas. Esse é o clima durante um sábado de carnaval entre Colégio e Rocha Miranda. "Pra onde você olha tem bate-bola", dizem eles. Interessante é que entre os cariocas conhecidos meus, que não tinham intimidade com essas áreas da cidade, quando eu falava em Bate-Bola, logo ativava neles uma espécie de nostalgia de um carnaval antigo, romântico, que praticamente não existia mais, sendo os Bate-Bolas uma espécie de tradição carnavalesca que teria já praticamente desaparecido. Definitivamente, as franjas dessa cidade guardam enigmas que sua centralidade romântica ignora, jogando, em um passado em vias de desaparecer, aquilo que é ainda absolutamente contemporâneo, presente.

Pois bem, virei à esquerda, mais uma à direita e cheguei a uma rua pequena, um tanto escondida, endereço da turma Legalize. A rua estava interditada para carros. Uma corrente, colocada pela própria turma, definia aquele espaço como interditado ao trânsito de carros e livre para a festa que mais tarde haveria de ocupá-la. O funk já tocava tão alto quanto nas outras duas. Pulei a corrente, liguei para o Robinho. 


\section{pro.posıções \\ $e$-ISSN 1980-6248}

http://dx.doi.org/10.1590/1980-6248-2016-0096

Figura 1 - Brasão da turma Legalize com a piXação, reparem, do Robinho ao lado

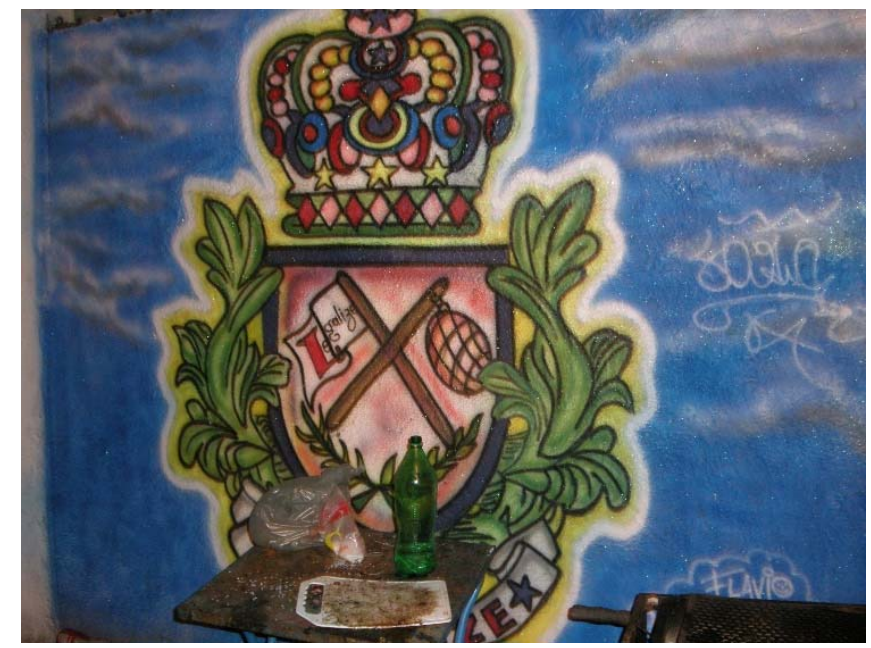

Fonte: Acervo do autor.

- Está vendo as caixas de som atravessadas aí na rua? - até então não tinha me dado conta, pois eu vinha ainda ao longe e por trás delas, então só via mais adiante uma enorme barreira de madeira. Eram as costas das caixas. Quando ele disse, percebi os cabos no chão e dei conta de que aquele volume ainda haveria de ser baixo, uma vez que estava do lado contrário da propagação do som.

- Ah sim, estou.

- Então, vem vindo que a garagem está aberta e é em frente. Pode chegar.

Assim que cheguei, passei pelas caixas e, ao lado do portão da garagem, um alto muro exibia o graffiti de um brasão formado por uma bandeira e uma bola atravessadas - as duas alegorias utilizadas pela turma. Entrei, avistei um grupo de rapazes ao fundo, ambos também com meia-calça azul e vermelha e uma camiseta que mantinha os mesmos motivos. Dois mais novos estavam sem camisa e com os cabelos pintados de vermelho. Olharam, estranharam, apresentei-me e perguntei pelo Robinho que, na sequência, saiu de dentro de casa.

- Opa, tudo bem? - cumprimentou-me estendendo a mão.

- Tudo bem. Bom, cheguei, e já passei por outras duas turmas no caminho.

- Ah sim, aqui tem um monte, você vai ver mais tarde. A cada hora uma sai e você ouve os fogos. Depois todas elas passam aqui na frente e ficam roando. 


\section{pro.posições}

$e$-ISSN 1980-6248

http://dx.doi.org/10.1590/1980-6248-2016-0096

- Ah, legal, vou ficar com vocês aí. E esses Xarpis ${ }^{5}$ todos aí? - perguntei apontando para seu muro interno que estampava uma série de nomes da piXação.

- Tudo amigo que vem aí e põe o nome. Põe lá o teu também, vai lá, eu tenho uma lata.

- Ab não, eu não ponho nome.

- Bom, tem lata aí, se quiser botar, é só falar. Olha, fica à vontade aí, tira as fotos, toma cerveja, come o churrasco que eu hoje estarei nessa loucura. Um monte de coisas pra resolver.

- Tudo bem, eu que agradeço, pode deixar que eu me viro.

Alguns meninos organizavam uma carreira de rojões, outros mais novos já testavam suas bolas, o que os levava a uma espécie de ensaio, uma vez que batê-la ao chão era um ato que envolvia todo um gestual largo, um gingado próprio, muitas vezes seguido de uma pequena corrida.

Figura 2 - Preparação de rojões

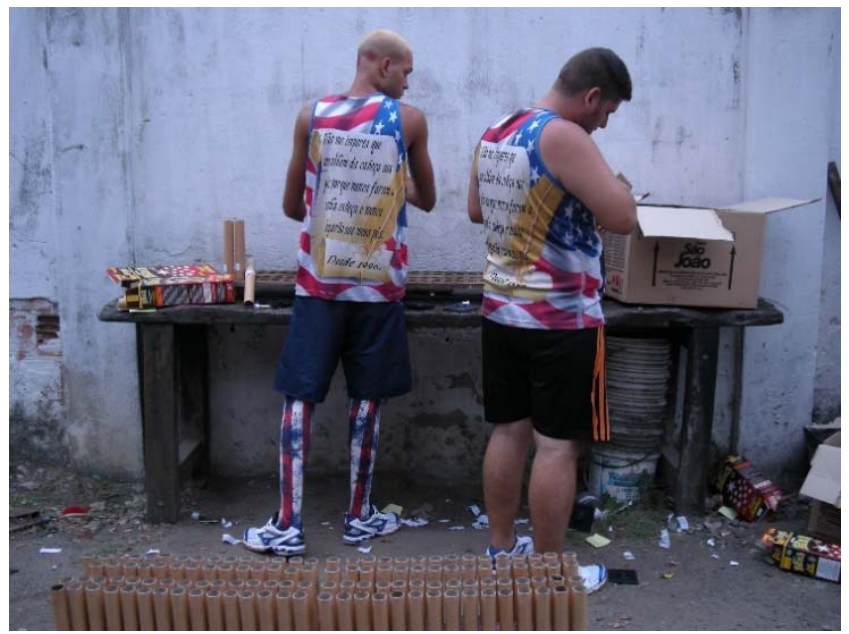

Fonte: Acervo do autor.

Fiquei por ali, fiz algumas fotos, conversei superficialmente com alguns, falei do meu interesse, da pesquisa e, enquanto isso, eles seguiam entre uma carne, uma cerveja, cumprimentos aos que chegavam, mas a principal atividade preparatória era a organização das

\footnotetext{
5 Se piXação é o nome dado nacionalmente a esse fenômeno, “xarpi” é sua expressão carioca. No Rio de Janeiro, há uma espécie de língua secreta falada entre alguns jovens que têm na rua uma zona de socialidade intensa. Chamase língua do TTK e funciona invertendo as posições silábicas das palavras, pondo a última na primeira posição e assim por diante. O nome TTK dizem que é por ter nascido nas ruas do Catete, bairro da Zona Sul do Rio. Assim sendo, nessa língua, "pixar" tornou-se "xarpi" e logo deixou de ser apenas verbo para tornar-se substantivo, sendo hoje sinônimo carioca para piXação.
} 


\section{pro-posıções}

$e$-ISSN 1980-6248

http://dx.doi.org/10.1590/1980-6248-2016-0096

carreiras de rojões. Diversas caixas empilhadas e, de um em um, iam encaixando numa base, o que já dava uma ideia da intensidade que acompanha o momento da saída da turma.

A fantasia em si tinha como tema os Estados Unidos. A camiseta que utilizavam enquanto não punham o bate-bola propriamente dito, estampava o Tio Sam. Já o colete, aí sim, já peça do bate-bola, exibia à frente uma índia e nas costas um índio, ambos em estilo americano. Perguntei a razão do tema ao Robinho, que disse:

- A turma se chama Legalize, né? E nos Estados Unidos tem muitos lugares que a maconha já é legalizada, então, virou tema desse ano.

Durante toda a tarde foi chegando cada vez mais gente, a cerveja seguia disponível em grandes tonéis desses azuis de guardar cloro, cheios de gelo. Robinho não parava um minuto, sempre resolvendo algum detalhe, especialmente referente à preparação dos fogos. Pelo celular, também acompanhava os últimos detalhes de um ou outro bate-bola que ainda estava passando por retoques na casa da costureira. No caso não era a Beth, já que parte das fantasias foram feitas também por outra costureira. Na parte interna da casa, um homem costurava à mão algumas bases de espuma aos coletes, o que lhes daria mais firmeza e volume.

Duas crianças brincavam com duas bolas, batendo-as, quando um rapaz já com seus quase 30 anos começou a pegar no pé de uma:

- Ih, qual foi moleque, o que que você está fazendo aqui? Você não é da outra turma?

- Sou - disse ele, já evidentemente intimidado.

- Então vaza pra lá, aqui só pode ficar quem é Legalize.

- Eu não...

- Ih, volta pra lá, moleque, para aquele teu bate-bola feio pra caralho. Pode falar, o teu bate-bola lá não é feio pra caralho?

- Não é nada.

- Olha, só vou deixar você ficar aqui se vocêfalar, fala vai "o meu bate-bola é feio pra caralho e o de vocês é muito mais bonito". Vai fala, se não vou te colocar pra fora.

- O meu bate-bola é feio...

- Isso, agora você pode ficar - disse, rindo. 


\section{pro.posıções}

$e$-ISSN 1980-6248

http://dx.doi.org/10.1590/1980-6248-2016-0096

Uma grande sequência de morteiros e outros fogos de artifício já se encontrava, então, dispostos em fila numa carreira que vinha desde a entrada até meados da garagem que, cabe dizer, era bem ampla, funcionando como um grande espaço anexo à casa. Robinho, então, trabalhava ainda avidamente na passagem do pavio que deveria encostar em todos os fogos para que fossem sendo disparados em sequência. Era um trabalho que necessitava de fineza no encaixe manual e olhar atento.

Figura 3 - Robinho arrumando os fogos

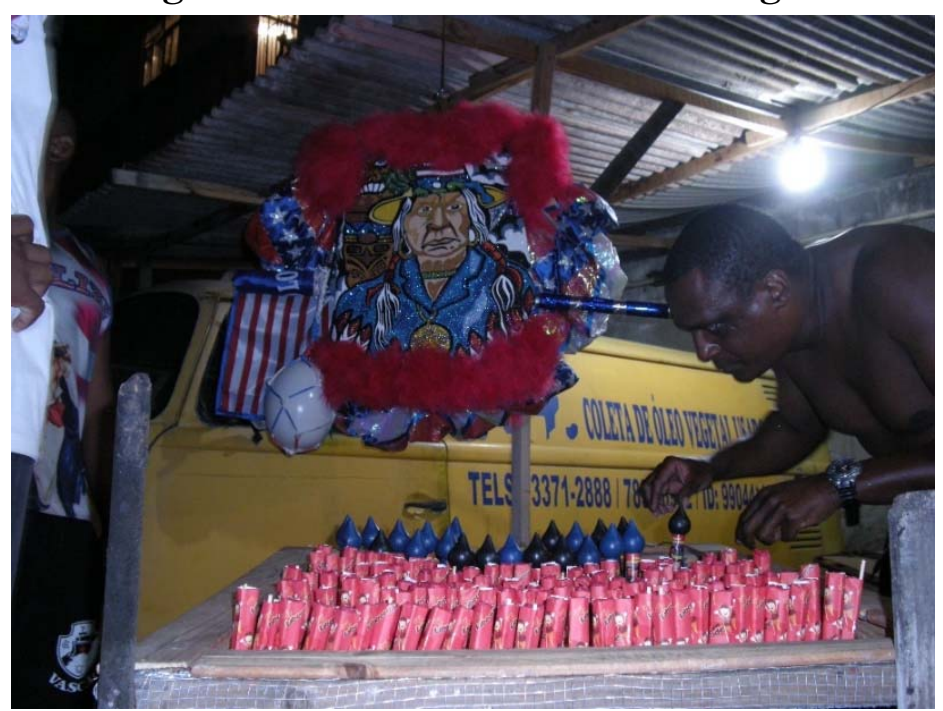

Fonte: Acervo do autor.

- Cara, eu já eston ficando vesgo. Não dormi direito essa noite e é melhor que outra pessoa mais descansada faça isso - disse Robinho.

- Quer que en ajude? - me dispus.

- Por favor.

- Só me explicar direitinho, pois nunca fiz isso.

Ele me ensinou a fazer o primeiro e dali em diante fui, um a um, encaixando cada foguete na grade de sustentação e passando o pavio. Nisso, outros dois rapazes que por lá estavam também se juntaram e, então, nós três, depois de uma meia-hora, terminamos o trabalho. Comecei, logo depois, a escutar uma sequência de fogos explodindo e um clarão no céu à esquerda. 


\section{pro.posições}

$e$-ISSN 1980-6248

- Se liga, é até bom parar pra ver - Marcelo chamou minha atenção. - É a turma da rua ao lado, os caras colocaram $\mathrm{R} \$ 3$ mil só em fogos.

E de fato foi uma longa e bonita sequência.

- Caralho, os caras "tão pica"! - exclamou alguém.

Figura 4 - Paredão de som

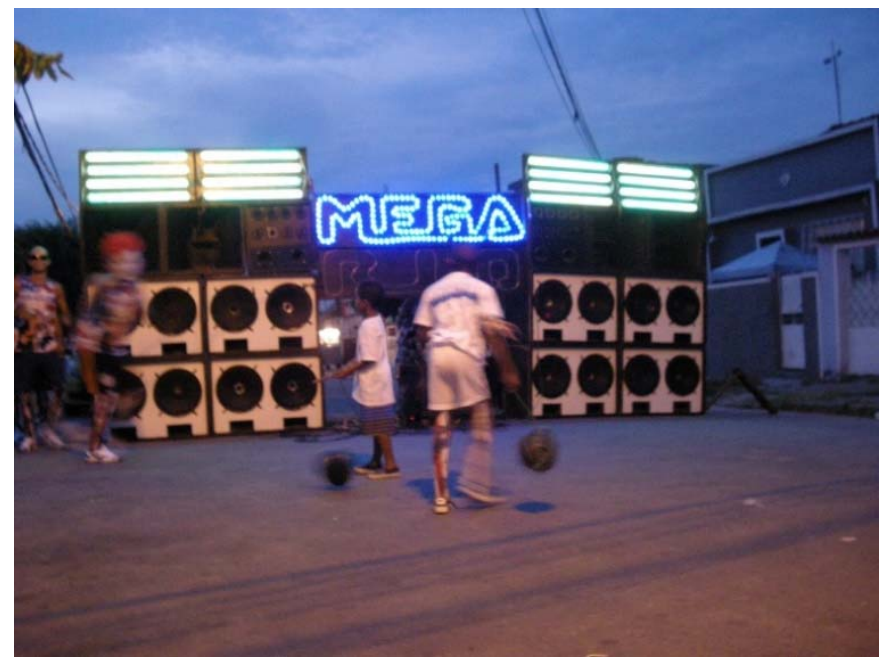

Fonte: Acervo do autor.

A noite já havia caído e a hora da saída se aproximava. A partir de então, havia um controle mais rigoroso quanto a quem podia entrar na garagem. À porta, a esposa do Robinho, Adriana, impedia a entrada de quem não fosse integrante ou outros poucos permitidos como eu. Era preciso preservar o bate-bola de sua revelação finalmente pública à rua. Ele só poderia dar-se à vista quando todo pronto, todos vestidos, devidamente ambientado com todo aparato de intensidades da saída - os fogos, o funk da turma e a coesão de grupo. Ao lado de fora, muita gente já estava aglomerada na expectativa, jovens dançando funk, barraca de cachorro-quente cheia, boteco fornecendo bebidas destiladas. Todos já ansiosos, haja vista que faltava chegar da costureira, de última hora, o colete de uma criança que havia dado algum problema.

Desde que eu chegara, ininterruptamente o paredão de som tocava funk. Não sei precisar quando, mas, em algum momento da noite, passou a tocar os proibidões eróticos que, a partir de então, deu a tônica da trilha da rua. Até que um homem bastante próximo de Robinho, mais velho e que parecia ter o respeito de todos ali, disse a um rapaz ao meu lado: 


\section{pro.posıções}

$e$-ISSN 1980-6248

http://dx.doi.org/10.1590/1980-6248-2016-0096

- Porra, não tenho nada contra a putaria, acho até gostoso, mas porra, está cheio de crianças e mulheres lá fora. Me diæz, você ia gostar de estar com sua mulher e ficar ouvindo essas baixarias? Vou lá dar o papo com todo respeito ao dj-imediatamente ele foi lá. Não sei como foi a conversa, mas o fato é que o funk "de putaria" seguiu tocando sem interrupções.

A hora ia passando e começavam, então, outras turmas de bate-bola que já haviam saído, a passar em frente à garagem, dançando, gingando, batendo suas bolas.

- Moleque, tá feio pra caralho! - um dos membros da Legalize ainda vestido de camiseta, disse a poucos centímetros do rosto de um dos bate-bolas que passavam em frente. Outros também faziam o mesmo, esculachavam verbalmente a beleza da turma rival. No entanto, era um escárnio em uma atmosfera de risos, pareciam, inclusive, muitos ali, se conhecerem.

- Pode falar que está bonito! Esculachamos, seus recalcados! - respondeu um deles.

Pelo menos umas quatro vezes cenas parecidas aconteceram, se dando sempre que outra turma, em suas andanças pelo bairro, passava em frente à garagem. Tratava-se de uma praxe, sair de sua garagem e ir a pé, circulando pelo bairro, passando na porta das demais para mostrarse, aos gestos alargados, exuberantes, deslocando-se mais aos pulos e balanços que por passos.

A roupa da criança chegou, cada um foi apressando o outro e, mutuamente, se ajudavam a fechar os zíperes das costas, os botões, afofavam os tecidos para garantir o volume da roupa. Ouvi, então, um rapaz falando com outro que não era bate-bola:

Figura 5 - Tênis com etiqueta exposta

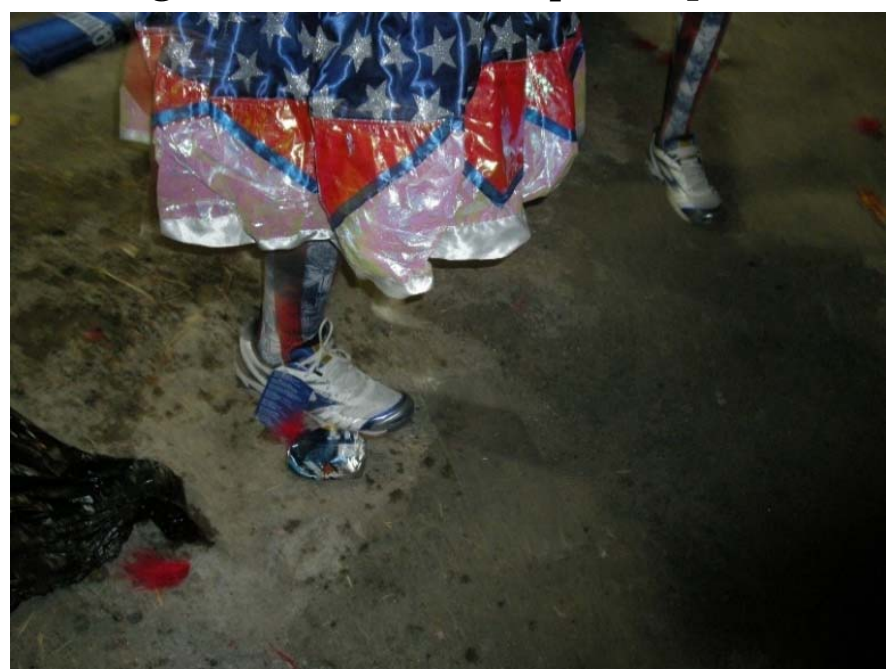

Fonte: Acervo do autor. 


\section{pro.posições}

$e$-ISSN 1980-6248

http://dx.doi.org/10.1590/1980-6248-2016-0096

- Porra, estamos pisando em $R \$ 800,00$ ! - e levantou os pés para mostrar o tênis Nike que mantinha pendurada a etiqueta de autenticidade. Que baita expressão, “pisar em R\$ 800,00”! Foi, então, que percebi que todos também trocaram seus calçados pelo mesmo modelo de tênis. Alguns mantinham as etiquetas, outros não, mas não se podia negar, pela aparência limpa dos calçados, que era o primeiro uso de todos.

Todos prontos, faltava a máscara. Aí que dei conta - tratava-se claramente da peça mais importante e, por isso, recebia, por parte do líder Robinho, um cuidado especial na preservação de seu segredo. Todos se reuniram, então, abaixo de uma escada que dava ao segundo andar da casa. Robinho e a esposa, lá de cima, anunciavam um número e, um por um, cada bate-bola se aproximava da escada para pegar sua máscara lançada lá de cima. Era evidente a ansiedade e a expectativa de todos em pegar a sua e vesti-la. Ao mesmo tempo, parecia que vesti-la e continuar com movimentos corporais sucintos era uma impossibilidade. Pô-la ativava uma espécie de "aquecimento". Corriam de um lado para o outro, gingando e batendo as bolas no chão, ainda na parte de dentro do portão de ferro, gritando, numa agitação que fora construindo ali, ainda inacessíveis à rua, um ambiente sonoro e visual análogo a um caos primordial que antecederia um nascimento - no caso, a saída. Imagino que as pessoas na rua também ouvissem esse crescente, essa massa de sons desgovernados e altos, o que, provavelmente, parecia anunciar que faltava pouco para a "estreia". Nisso, muitos dos que como eu ali estavam, mas não eram "bate-bolas", parentes, amigos próximos, iam sacando suas câmeras, seus celulares, enquanto eles se exibiam, abriam braços e pernas o máximo possível, distendendo-se ao máximo, exibindo uma expansão para a qual a quantidade de tecidos era a metáfora, o contorno tangível. Chegara a hora. Robinho convocou todos ao centro da garagem:

- Atenção, todo mundo aqui, todo mundo aqui. Juntou? Silêncio, porra! Olha só! Não importa o que aconteceu, ninguém está aqui pra julgar ninguém. A gente vai sair agora em silêncio, vamos lá fora, vamos fazer nossa oração lá do lado de fora e vamos voltar pra cá pra dentro pra gente arrebentar aquela porra! - ao que se seguiram gritos de euforia de todo o grupo.

Quando foram saindo, gritos de todo lado pediam calma, pediam para ninguém correr, para que todos saíssem juntos. Ninguém batia suas bolas. Um silêncio foi sentido. Outra preocupação também foi significativa. Ouvi alguém dizendo:

- Levanta a máscara geral, todo mundo sem máscara em respeito ao amigo que morreu! 


\section{pro.posições}

$e$-ISSN 1980-6248

http://dx.doi.org/10.1590/1980-6248-2016-0096

Robinho foi então ao microfone, perguntou se todos estavam ali e iniciou um Pai Nosso e uma Ave Maria. Voltaram todos para dentro e poucos minutos depois, agora sim mascarados e acompanhados de toda a sequência explosiva de fogos, saíram pulando, gingando, batendo efusivamente as bolas, enquanto o funk da turma era tocado, funk que também fazia alusão ao amigo falecido. O público do lado de fora fazia um círculo deixando ao meio uma clareira para que eles exibissem sua eloquência corporal. Chegavam bem próximos dos rostos das pessoas, não poupavam as crianças do medo incutido. "É a Legaliže, porra!" - era o grito mais ouvido, um anúncio da força grupal. Um êxtase ia gradativamente contaminando os gestos cada vez mais largos, até que alguns chegaram a se jogar de costas no asfalto com pernas e braços bem abertos, uma espécie de mimese da morte, do esgotamento. Por alguns segundos, ficavam ali parados para depois se levantarem e seguirem bailando, movimento que não fora apenas uma expressão individual, mas que é repetido nas saídas de qualquer turma de bate-bolas pelo Rio de Janeiro. Fiquei ali como público, filmando com uma pequena câmera, quando um dos meninos mais novos veio na minha direção, bem próximo do meu rosto e, rindo, forçou com alguma pressão o bastão da bola na minha cintura, virando-se logo na sequência para seguir bailando. Na hora, senti que aquele golpe era uma pancada ambivalente, ao passo que marcava minha posição exterior, também me recebia, inscrevia meu corpo naquela presença. Em todo caso, tomado pela exuberância da situação, não me atentei a olhar o local golpeado. Somente no dia seguinte, ao acordar, quando senti o local dolorido, é que pude perceber que havia sido, de fato, batizado, um hematoma roxo estampava minha cintura.

\section{Figura 6 - O Bate-Bola pronto}

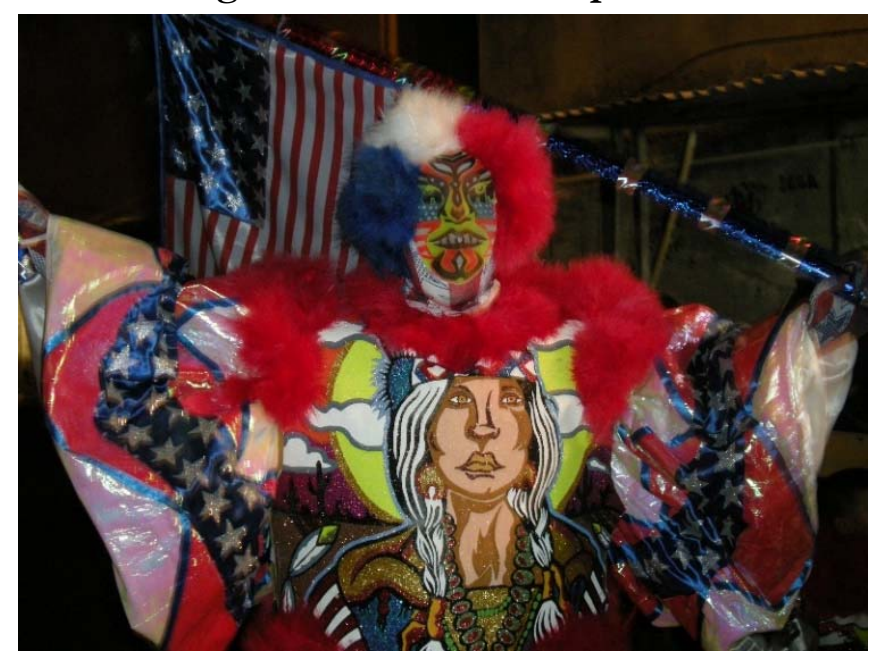

Fonte: Acervo do autor. 


\section{pro.posições}

$e$-ISSN 1980-6248

http://dx.doi.org/10.1590/1980-6248-2016-0096

A quantia gasta com os fogos, o montante colocado na fantasia, os litros de cerveja e os quilos de carne, a potência sonora, os gestos expandidos e uma bola que bate vibrada por essa expansão, jogar-se esgotado ao solo e depois levantar-se, pisar numa boa soma de dinheiro, depois, como fazem alguns, queimar tudo numa fogueira na praça, e tudo isso, tendo, como esses jovens têm, uma condição financeira que provavelmente não lhes garante a melhor das capacidades econômicas, parece-me cenário fortuito a encontrar com exuberância essa faculdade que Bataille julgou atrofiada no homem moderno, essa saúde pelo dispêndio, esse prazer pela perda proposital e suntuosa, casos em que "a ênfase é colocada na perda que deve ser a maior possível para que a atividade adquira seu verdadeiro sentido" (Bataille, 2013, p. 21). Perda que, para o próprio Bataille (2013), fundamenta o sacrifício como instituição humana, o qual não seria "outra coisa, no sentido etimológico da palavra, que não a produção de coisas sagradas" (p. 22).

Nessa reflexão, então, Bataille propõe uma inversão na lógica, destituindo a centralidade da aquisição, corrente na maneira econômica de entender o mundo por um positivismo moderno burguês, e realoca em seu lugar a noção de dispêndio, principalmente inspirado pelos estudos sobre a dádiva de Marcel Mauss (2013), o qual percebera tanto em tribos do noroeste americano, quanto na Melanésia, a importância proeminente das trocas dispendiosas em seu "comércio" de dádivas. Entre os envolvidos nesse fluxo, então, Mauss percebera a ausência completa da noção de lucro, no sentido acumulativo que normalmente o empregamos, mas, ao contrário, a obrigatoriedade implícita do gasto. Resumidamente, aquele que recebia uma série de objetos valorizados de determinado clã, recebia junto, implicitamente, a obrigação de retribuir com um gasto ainda mais suntuoso, de "retribuir com usura" (Bataille, 2013, p. 25), sendo um possível manejo mesquinho e egoísta desse fluxo, combatido veementemente pela tribo, até mesmo com guerras coletivas. Se houvesse, então, alguma "lucratividade" nesse jogo, era aquela imaterial, sagrada, a dádiva propriamente dita que a gastação provia ao grupo e que, de certa forma, como na sua introdução apontou o próprio Mauss (2013), segue presente de maneira subjacente em nossas vidas contemporâneas: “ assim [ainda] rivalizamos em nossos brindes de fim de ano, em nossos festins, bodas, em nossos simples convites para jantar, e sentimo-nos ainda obrigados a nos revanchieren ${ }^{6}$, como dizem os alemães"(pp. 16-17).

6 “Thurnwald (1912, t. III: 8) emprega a palavra, que significa 'desforrar-se', 'dar o troco”' (Mauss, 2013, p. 148). 


\section{pro.posıções}

$e$-ISSN 1980-6248

http://dx.doi.org/10.1590/1980-6248-2016-0096

Segue-se, então, mais um exemplo de como, nos mais diversos cenários, é a propriedade acumulada de todo tipo que vai receber a desconfiança do grupo, uma vez que contém em si também potencialmente a dissolução dos laços comunais. Assim, portanto, ainda mais intensificada pela condição despossuída da juventude que a protagoniza, tratando-se então de perdas sem reservas ("se joga", "queima tudo", "torra tudo", dizem eles), esses dispêndios contemporâneos populares tanto de si, quanto das coisas, assim como do sentido atribuído às coisas, parecem manter resistência epistêmica às lógicas tradicionais da economia que, por razões óbvias, só viam nas trocas arcaicas o escambo com o objetivo de lucro, concepção conservadora que buscava legitimação em alguma natureza humana, aos seus frenesis acumulativos e consequentemente à miséria, visão que fora desmantelada por esses estudos de Mauss, no qual, como vimos, o que era convocado a circular para a nutrição comunal, não era a mesquinhez egoísta, mas a riqueza coletiva desprendida. Em todo caso, ao que parece, em meio à aparente miséria que a cidadela romântica lança os bairros de suas franjas, lá se encontra em exuberância esse alimento que tanto faz falta ao centro desnutrido, esse destaque que é dado à experiência estética comum e seus excessos. "Por mais pavorosa que seja, a miséria humana nunca exerceu suficiente influência sobre as sociedades para que a preocupação com a conservação, que dá à produção a aparência de um fim, prevalecesse sobre a preocupação com o dispêndio improdutivo" (Bataille, 2013, p. 24).

Cabe destacar uma importância fundamental que a condição "sem reservas" tem na potencialização do sentido sacrificial e comunal do dispêndio que aqui nos interessa. Afinal de contas, é evidente que grandes fortunas também são capazes de produzir estonteantes banquetes e festas das mais desregradas e eufóricas. De todo modo, nesses casos, a robustez da "reserva estável", da qual esse dispêndio economicamente seguro retira seu gasto, funciona como uma garantia de "si" que acaba sendo definitiva ao mais enfraquecido poder de "entrega" dessas ocasiões, uma vez que, mesmo havendo um orçamento altíssimo, não há verdadeiramente propriedades em risco de dissolução. E ainda nos casos das fortunas em decadência que, frequentemente, mesmo sob o assombro das dívidas, não abrem mão irresponsavelmente de manter a "pose", as seguidas possíveis festas dispendiosas acabam servindo mais para, mesmo sobre um já esvaziado banco de propriedades, "parecer" ainda ser um grande acumulador.

No nosso caso, os $\mathrm{R} \$ 3$ mil explodidos pelos bate-bolas vizinhos em fogos de artifício, sendo algo para que Marcelo fez questão de chamar minha atenção, afinal mereciam admiração, 


\section{pro.posições}

$e$-ISSN 1980-6248

http://dx.doi.org/10.1590/1980-6248-2016-0096

é choque epistemológico potente na mesquinharia que a racionalidade moderna chamou de virtude e que Castoridias (2009) chamou de "ilusão de acumulação aquisitiva"(p. 29), que Nietzsche (2007, p. 45) chamou de toda "ponderação" e "medida" em que o homem "submergiu no esquecimento de si", que Maffesoli (1985) chamou de "moral econômica que funciona sempre por conta do amanhã" (p. 25), contra a qual o dispêndio seria "mais fecundo que a estreita e imperiosa imposição da produção", ou uma "mais-valia vital" (p. 43).

Por fim, então, trago uma última imagem, que é apenas uma entre tantas outras desse vasto repertório de expressões poéticas sedimentadas nessas culturas jovens, mas que parecem ser resultantes de incalculáveis saberes ancestrais como que depositados em nossas heranças subjetivas. Basta, então, um ambiente mais propício, como esses, ou uma singularidade menos coagida, como a desses meninos e meninas, para o não pensado sair de sua condição invisível, embora sempre atuante, para ganhar corpo, tornar-se tangível. Talvez seja esse o papel tanto das culturas populares, quanto dos poetas, dos artistas - o de tornar tangível, o de tornar sensorialmente experimentável, esse mar de águas revoltosas, escuras e desconhecidas que compõem a maior parte de nossa vida psíquica, podendo assim, diante delas, sob a forma de fantasias, poéticas, pixos, máscaras monstruosas, finalmente domá-las. Justamente, como aponta Turner (1974), ao se aproximar da psicanálise:

Corporificar a ação invisível de feiticeiros e sombras em um símbolo visível ou tangível é um grande passo no sentido de remediá-la. Isto não está muito longe da prática do moderno psicanalista. Quando algo é apreendido pelo espírito, quando se torna um objeto capaz de ser pensado, pode ser enfrentado e dominado. ( p. 42)

Digamos, então, que todo o sistema no qual a psicanálise investiu seus estudos já operava no nível do inconsciente há milhares de anos. Nesse sentido, Turner (1974) também reconhece o impacto decisivo do que herdamos de toda história humana naquilo que conseguimos expressar:

Esses processos libertam seguramente energias instintivas, porém estou agora inclinado a pensar que a communitas não é apenas produto de impulsos biologicamente herdados, liberados das coações culturais. São antes produtos de faculdades peculiarmente humanas, incluindo a racionalidade, a volição e a memória, desenvolvidas pela experiência da vida em sociedade. (p. 156)

Vamos então à imagem e a quais os saberes ancestrais de que ela depende para emergir: 


\section{pro.posıções}

e-ISSN 1980-6248

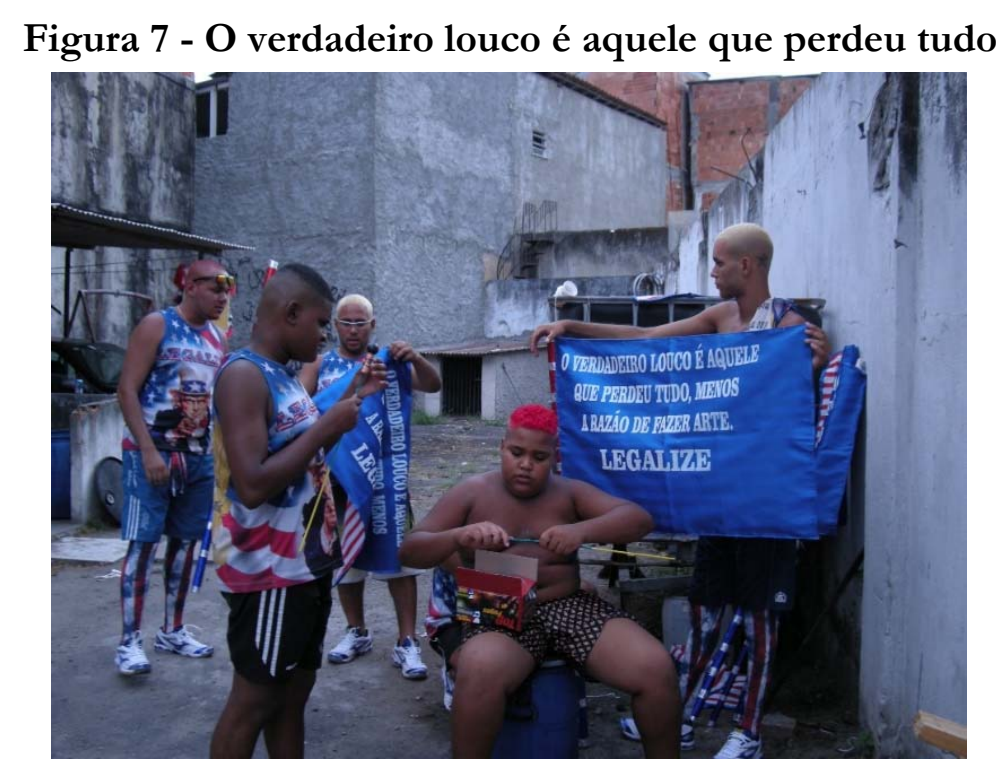

Fonte: Acervo do autor.

Quando esses meninos escrevem "perdeu tudo", pergunto-me o que de nós é "perdível”, e o que de nós, independente de nosso desejo e de qualquer coerção, permanece em nós; ou seja, pergunto-me o que seria esse "tudo". "Tudo" o que lhe confere distinção, seus títulos, nomes, sobrenomes, posições sociais, prestígios, ou seja, todas suas propriedades que compõem seu lugar na estrutura social, tudo isso, como nos ensinaram tantos e tantos povos, pode ser "perdível". Voltando ao início do nosso artigo, tudo aquilo que Nuno despossa de Leandro para se constituir, tudo aquilo que Tatá suspende no João para fruir. Em outras palavras, tudo o que fortalece sua armadura individual e que sustenta sua compatibilidade ao mundo "real" é "perdível", e é justamente dessa zona liminar (Turner, 1974), aberta pelas fissuras das propriedades suspensas que, como vimos, a "communitas" emerge. Sem o mundo "real" como estrutura de proteção à emersão da poética, essa encontra caminho à superfície tangível, e esse corpo desapossado de condecorações, temporariamente incompatível à "realidade", Nunos, Tatás, Bate-Bolas, com a força da fragilidade do corpo nu desarmadurado desses jovens, "louco", portanto, justamente subjetividades das mais negligenciadas de nossas escolas e cidades, tornam-se ótimos condutores de poética, de arte e de conhecimento no seu sentido mais amplo. Sem explicar, então, oferecem em suas performances, em seus acabamentos éticos e estéticos, focos deste artigo, bons indicativos para entendermos as razões epistemológicas de suas incompatibilidades ao receituário normativo, ou seja, escancaram em seus jeitos os limites economica e libidinalmente miseráveis das máquinas de subjetivação que fomentam suas exclusões; justamente porque não cabem, transbordam. 


\section{pro.posıções}

$e$-ISSN 1980-6248

http://dx.doi.org/10.1590/1980-6248-2016-0096

\section{Referências}

Bakhtin, M. (2013). A cultura popular na Idade Média e no Renascimento: o contexto de François Rabelais. São Paulo: Hucitec.

Bataille, G. (2013). A parte maldita, precedida de "A noção de dispêndio”. Belo Horizonte: Autêntica.

Canevacci, M. (2005). Culturas eXtremas: mutações juvenis nos corpos da metrópole. Rio de Janeiro: DP\&A.

Castoriadis, C. (2009). Janela sobre o caos. São Paulo: Ideias e Letras.

Maffesoli, M. (1985). A sombra de Dionísio: contribuição a uma sociologia da orgia. Rio de Janeiro: Graal.

Mauss, M. (2013). Ensaio sobre a dádiva: forma e razão da troca nas sociedades arcaicas. São Paulo: Cosac Naify.

Nietzsche, F. (2007). O nascimento da tragédia. São Paulo: Escala.

Turner, V. (1974). O processo ritual: estrutura e anti-estrutura. Petrópolis: Vozes.

Submetido à avaliação em 4 de julho de 2016; revisado em 25 de novembro de 2016; aceito para publicação em 21 de dezembro de 2016. 